TERMINUS

t. 20 (2018), z. 2 (47), s. $165-193$

doi: $10.4467 / 20843844$ TE. 18.006 .9751

www.ejournals.eu/Terminus

Magdalena Ryszka-Kurczab

http://orcid.org/0000-0002-4175-9414

Uniwersytet Pedagogiczny w Krakowie

magdalena.ryszka-kurczab@up.krakow.pl

\title{
„Aby każdy miłośnik prawdy onej szukając, z czytania jej dojść mógł”. Sposoby uwiarygodniania przekazu w szesnastowiecznych relacjach z polskich dysput wyznaniowych
}

\begin{abstract}
"May every lover of truth find it through reading." Manners of Authenticating the Message in Sixteenth-Century Accounts of Polish Religious Disputations
\end{abstract}

In the $16^{\text {th }}$ and $17^{\text {th }}$ centuries, religious disputations became one of the means of conducting religious agitation. Texts providing an account of the course of such events confirm the application of the formal rules of school-type disputatio in public disputes using vernacular language. This undoubtedly resulted in the expansion of the audience at such spectacles beyond scholars conversant in Latin and influenced the change of the objectives of such debates, from a collective search for the truth to the defence of one's own doctrine using all available methods, that is, dialectics and rhetoric.

Unlike mediaeval scholastic disputations, public disputes no longer engaged an arbiter to settle them. The victory was decided by the very course of the dialectic confrontation. As a matter of fact. The lack of an authoritative arbiter encouraged each of the parties involved to assure the public that they had won and therefore that their religious statements were true. After such a confrontation, ostensibly im- 
partial and true accounts of the course of the dispute were published in print. This paper presents an analysis of eight prints providing detailed descriptions of six religious debates conducted in Polish between 1581-1599. These texts reaffirm the conviction (inherited from the Middle Ages) that the truth may be learnt through disputatio. They explicitly express the belief in the readers' ability to individually assess the correctness of the arguments formulated and the counterarguments, and consequently to understand who is right. At the same time, noticeable techniques employed to authenticate the accounts as impartial and true dispiteously undermine the objectivity of the accounts that profess to be true. The discursive means employed to direct the reader in his reception of the conveyed message include a declaration of an ethical urge to proclaim the truth about the course of the debate and its winners, and concealment of the true authorship of the text with the aim of avoiding a charge of partiality, assuring that the account follows the pattern of the so-called autentyki (or originals), that is notes written down during the dispute.

Keywords: Polish religious disputations, accounts of disputations, early modern period, authenticating accounts, rhetorical strategies, dialectics

\section{Publiczne dysputy wyznaniowe}

Publiczne dysputy wyznaniowe były niewątpliwie jedną z metod prowadzenia religijnej agitacji na terenie Rzeczypospolitej od połowy wieku XVI i w wieku XVII. Choć niektóre z nich odbijały się szerokim echem i inspirowały do kontynuowania polemiki - albo w formie kolejnej dysputy, albo wymiany pisemnej - to wydaje się, że wciąż nie zostały wyczerpująco opisane i wyzyskane badawczo ${ }^{1}$.

1 Spośród szczupłej bibliografii wymienić należy: artykuł Stanisława Tworka, Dysputa lewartowska w 1592 roku, „Rocznik Lubelski” 3 (1960), s. 51-62, oraz tekst Janusza Tazbira, który poświęcił artykuł dyspucie między Jakubem Niemojewskim a Franciszkiem Toledo (Warszawa 1572) oraz planowanej dyspucie między Jakubem Niemojewskim a poznańskimi jezuitami, która ostatecznie nie doszła do skutku: Polemika Jakuba Niemojewskiego z jezuitami poznańskimi, w: Munera Poznaniensia. Księga pamiątkowa Uniwersytetu im. Adama Mickiewicza w Poznaniu dla uczczenia 600-lecia założenia Uniwersytetu Jagiellońskiego, red. G. Labuda 1965, s. 236-260. 
W związku z niedostatecznym stanem badań szczegółowych nad publicznymi dysputami wyznaniowymi trudno wydawać kategoryczne sądy na temat samej metody bądź metod prowadzenia dysputacji na terenie Korony i Litwy. Można co najwyżej sformułować ogólne twierdzenie - zbieżne $\mathrm{z}$ badaniami nad dysputami $\mathrm{z}$ okresu renesansu w krajach Europy Zachodniej² - że poświadczają one

Ponadto: K. Drzymała, Ks. Marcin Śmiglecki T.J., Kraków 1981, s. 23-24 i 34-40, J. Kamieniecki, Zasady prowadzenia dyskursu religijnego zawarte $w$ staropolskich tekstach polemicznych, w: Wyrazi zdanie w językach słowiańskich. Opis, konfrontacja, przekład. 7, red. M. Sarnowski, W. Wysoczański, Wrocław 2009, s. 93-100; M. Ryszka-Kurczab, Kilka uwag o Dysputacyjej Księdza Hieronima Powodowskiego $z$ ministrem zboru nowoariańskiego śmigielskiego Janem Krotowicjusem $z 1581$ roku, w: Rzeczy minionych pamięć. Studia dedykowane Profesorowi Tadeuszowi Ulewiczowi w 90. rocznicę urodzin, red. A. Borowski, J. Niedźwiedź, Kraków 2007, s. 449-462. Ogólne wzmianki na temat publicznych dysput wyznaniowych można napotkać w: W. Stec, Literacki ksztalt polskich polemik antyjezuickich z lat 1578-1625, Białystok 1988; J. Tazbir, Rola żywego słowa w polskiej propagandzie wyznaniowej, „Kwartalnik Historyczny” 87 (1980), nr 2, s. 291-309; Dysputacje arian polskich, wydał i wstępem poprzedził S. Kot, „Reformacja w Polsce” 7 (1935), s. 341-370; S. Kot, Dysputacyj braci polskich katalog z rękopisu Andrzeja Lubienieckiego młodszego, „Reformacja w Polsce” 9-10 (1939), s. 456-464; B. Natoński, Humanizm jezuicki i teologia pozytywno-kontrowersyjna od XVI do XVIII wieku. Nauczanie i piśmiennictwo, Kraków 2003 (pierwsze wyd. w: Dzieje teologii katolickiej w Polsce, t. 2: Od odrodzenia do oświecenia, cz. 1: Teologia humanistyczna, red. M. Rechowicz, Lublin 1975).

2 Zob. zwłaszcza: O. Weijers, Renaissance Disputation, w: eadem, In Search of the Truth. A History of Disputation Techniques from Antiquity to Early Modern Times, Turnhout 2013, s. 177-207; eadem, The Development of Disputation Between the Middle Ages and Renaissance, w: Continuities and Disruptions Between the Middle Ages and the Renaissance. Proceedings of the Colloquium Held at the Warburg Institute, 15-16 June 2007, Jointly Organised by the Warburg Institute and the Gabinete de Filosofia Medieval, ed. by C. Burnett, J. Meirinhos, J. Hamesse, Louvainla-Neuve 2008, s. 139-150; D.L. Felipe, The Post-Medieval ars disputandi, Austin 1991; J. Rodda, Public Religious Disputation in England, 1558-1626, Farnham 2014; I. Angelelli, The Techniques of Disputation in the History of Logic, „Journal of Philosophy" 67 (1970), s. 800-815; U. Paintner, Aus der Universität auf den Markt. Die disputatio als formprägende Gattung Konfessioneller Polemik im 16. Jahrhundert am Beispiel antijesuitischer Publizistik, w: Disputatio 1200-1800. Form, Funktion 
wczesnonowożytne przemiany dysputy scholastycznej, rozwiniętej i wysubtelnionej na średniowiecznych uniwersytetach. Przemiany spowodowane były zarówno włączeniem do istniejącej praktyki dysputacyjnej nowych elementów humanistycznego nauczania, jak i potrzebą propagandy reformacyjnej, która pchnęła disputatio z sal uniwersyteckich na place i do kościołów, czyniąc $\mathrm{z}$ dysputy oręż $\mathrm{w}$ walce wyznaniowej. To właśnie potrzeby religijnej propagandy kazały zastępować łacinę (bezwzględnie zarezerwowaną dla dysputy uniwersyteckiej aż do wieku XVIII³) językiem narodowym. Niewątpliwie umożliwiło to znaczne poszerzenie kręgu odbiorców poza grono scholarów biegłych w łacinie i dialektyce, miało jednak ważkie konsekwencje dla samej metody oraz funkcji, jakie dysputa zaczęła pełnić pośród reformacyjnych sporów religijnych.

Jedną z fundamentalnych cech średniowiecznej dysputy było jej nastawienie na kolektywne poszukiwanie prawdy4. Po zakończonej disputatio bezwzględnie wymagano, aby w relatywnie krótkim terminie $^{5}$ mistrz, który dysputę organizował i jej przewodniczył (praeses), dostarczył pisemną determinatio (determinatio magistri), czyli tekst, w którym wskazywał właściwą odpowiedź na pytanie postawione w quaestio oraz uzasadniał swoje stanowisko i odpierał wysuwane wobec tego stanowiska zarzuty. Tymczasem formuła publicznych, pozaszkolnych dysput wyznaniowych organizowanych w XVI i XVII stuleciu w Europie, również w Polsce, nie przewiduje już dłużej in-

und Wirkung eines Leitmediums Universitarer Wissenskultur, hrsg. von M. Gindhart, U. Kundert, Berlin-New York 2010, s. 129-154.

3 K. Chang, From Oral Disputation to Written Text. The Transformation of the Disputation in Early Modern Europe, „History of Universities” 19 (2004), no. 2, s. $137-138$.

4 O. Weijers, Disputation in the Medieval Universities. General Analysis, w: eadem, In Search of the Truth..., s. 131 i nn. oraz 138-141; J. Rodda, Public Religious Disputation..., s. 10 i nn.; P. Gondek, Dysputa scholastyczna jako przykład sporu naukowego, „Forum Artis Rhetoricae” 3 (2014), s. 7-22.

5 Poszczególne uniwersytety czy nawet wydziały miały w tym względzie własne szczegółowe regulacje, zob. O. Weijers, Disputation in the Medieval Universities..., s. 129-131. 
stancji, która rozstrzyga spór. W słynnej lipskiej dyspucie (1519) między Marcinem Lutrem a Johannesem Eckiem książę saski Jerzy Brodaty przesłał następnie zapis jej przebiegu na wydziały teologiczne uniwersytetów w Paryżu oraz Erfurcie, mając nadzieję, że w ten sposób uda się zachować bezstronność. Oba uniwersytety uchylały się od zajęcia stanowiska ${ }^{6}$. Adwersarze w dyspucie wyznaniowej nie akceptują wspólnie żadnej instancji, która mogłaby poświadczyć swym autorytetem zwycięstwo którejś ze stron sporu. O wygranej ma tu niejako decydować sam przebieg dysputy. Milcząco zakłada się, że zwycięstwo stanie się udziałem tej strony, która wygra w dialektycznej rozgrywce, czyli dialektycznymi metodami będzie w stanie lepiej odegrać swoją dysputacyjną rolę, wzorowaną na modelu szkolnym: respondens - broniąc przedstawionej tezy przez odparowywanie kontrargumentów adwersarza, opponens zaś - poprzez nakłonienie przeciwnika do akceptacji tezy sprzecznej z bronioną. Zwycięzca miałby zostać wyłoniony obiektywnie i miałoby to być oczywiste dla wszystkich obecnych. Tymczasem wielogodzinne dysputy wyznaniowe nigdy nie kończyły się jednoznacznym triumfem którejś ze stron. W rzeczywistości dysputanci wikłali się w dialektyczne niuanse, w terminologiczne rozróżnienia, w rozbieżne interpretacje fragmentów Pisma, usiłując za wszelką cenę odnieść zwycięstwo. Drobna, choć w istocie fundamentalna zmiana, jaką był brak instancji powołanej do autorytatywnego stwierdzania zwycięstwa którejś strony, zachęcała do utwierdzania na własną rękę szerokiej publiczności w przeświadczeniu o porażce przeciwnika. W rezultacie po zakończonej dyspucie zazwyczaj przynajmniej jedna ze stron, a często obie, wypuszczała drukiem relację z przebiegu starcia. Było to przedstawienie własnej wersji zdarzeń, w której usiłowano zdyskredytować oponentów, a przede wszystkim obnażyć po ich stronie

6 Por. R.H. Fife, The Revolt of Martin Luther, New York-London 1957, s. 369 i nn.; S.H. Hendrix, Martin Luther. Visionary Reformer, New Haven 2015, s. 80. Przymuszony Uniwersytet Paryski zajął stanowisko dopiero w 1521 roku (dwa lata po dyspucie). 
brak solidnych argumentów na poparcie własnego stanowiska, mający stanowić oznakę fałszu konkretnych twierdzeń. Równocześnie cały czas usiłowano przekonywać czytelnika, że jest to obiektywny opis wydarzeń. Sięgano więc po techniki uwiarygodniania przekazu jako bezstronnego, które służyły sterowaniu lekturą. Można zatem powiedzieć, że renesansowe publiczne dysputy wyznaniowe są $\mathrm{z}$ jednej strony spadkobierczyniami tradycji scholastycznych dysput uniwersyteckich, z drugiej jednak tylko pozornie mogą służyć temu samemu celowi: poszukiwaniu prawdy. W rzeczywistości celem dysputacji nie było już dłużej otwarte testowanie hipotez naukowych czy uzasadnień teologicznych, jak w okresie wcześniejszym, lecz obrona doktryny za wszelką cenę oraz wszelkimi dostępnymi metodami dialektyki i retoryki.

W artykule analizom poddano przede wszystkim teksty przynależące do tak zwanej ramy wydawniczej (dedykacje, przedmowy do czytelnika, ewentualne zakończenia) oraz fragmenty relacjonujące okoliczności zorganizowania dysputy, a także przemowy dysputantów, które tradycyjnie wygłaszano przed samym starciem, a które $\mathrm{w}$ drukach zgodnie $\mathrm{z}$ chronologią poprzedzają właściwe relacje $z$ dysput. Nie znaczy to wcale, że opisy samych dysputacji mają charakter bezstronny i ściśle merytoryczny. Nawet teksty, które szczegółowo odzwierciedlają naprzemienne posunięcia dysputantów, nie są wolne od odautorskich komentarzy i nacechowanych pejoratywnie lub aprobatywnie fraz, mających kształtować opinie czytelnika o sprawności logicznej dysputantów, dopuszczalności lub nie danego dialektycznego kroku. Jednak opis stosowanych w dysputacjach metod dialektycznych oraz sposób oceniania poprawności lub niedopuszczalności posunięć adwersarza wymaga bezwzględnie osobnego i obszernego studium. Opis taki z konieczności musi odwoływać się do ówczesnej kultury logicznej i jej praktycznych przejawów, a ponieważ brak szczegółowych studiów na temat szesnastowiecznej ars disputandi na terenach Korony i Litwy, trudno przedstawić tak złożone zagadnienie w artykule o bardzo ograniczonej objętości. Tymczasem teksty okalające opisy samych dysput pozwalają nam dostrzec napięcie związane $\mathrm{z}$ jednej strony $\mathrm{z}$ deklarowaną wiarą $\mathrm{w}$ dysputę 
jako narzędzie, może już nie tyle poszukiwania prawdy, co tej prawdy wykazywania, z drugiej zaś ujawniają strategie uwiarygadniające sam przekaz (nieuchronnie zagrożony stronniczością) oraz służące sterowaniu lekturą.

\section{Charakterystyka źródeł}

Podstawę analiz stanowi zasadniczo osiem druków dotyczących sześciu publicznych dysput wyznaniowych z lat 1581-1599. Wszystkie zostały zorganizowane po polsku. Chronologicznie były to:

1) Dysputa w Śmiglu z 27 grudnia 1581 roku. Wzięli w niej udział: ze strony katolickiej Hieronim Powodowski, ze strony braci polskich - Jan Krotowski (Krotowicjusz, Krotovius), ówczesny minister zboru ariańskiego w Śmiglu? nego bóstwa Chrystusa. Przebieg dysputy poświadcza tekst wydany rzekomo przez Sebastiana Szamotulskiego, choć niewykluczone, że autorem był sam Powodowski, Dysputacyja o niektórych artykułach przedwiecznego Bóstwa Syna Bożego i Trójce Przenaświętszej.

2) Dysputa lewartowska z 13-14 stycznia 1592 roku. Była to dysputa trójstronna: pierwszego dnia starli się Adrian Radzymiński SI oraz Wojciech z Kalisza (Calissius), rektor szkoły unitariańskiej w Lewartowie. Calissius atakował tezę o przedwiecznym bóstwie Chrystusa. Drugiego dnia Radzymiński dysputował z ministrem kalwińskim Grzegorzem Jankowskim, tematem była sporna między katolikami i kalwinistami kwestia transsubstancjacji. Wydany ano-

Zob. L. Gomolec, Dzieje miasta Śmigla, Poznań 1960, s. 50.

8 S. Szamotulski [H. Powodowski?], Dysputacyja ks. Hieronima Powodowskiego z ministrem zboru nowoariańskiego śmigielskiego Janem Krotowicjuszem, o niektórych artykułach przedwiecznego Bóstwa Syna Bożego i Trójce Przenaświętszej, tamże w zborze śmigielskim odprawowana [...] dnia 27 grudnia w roku 1581, [Poznań: Jan Wolrab, 1581] (Biblioteka Książąt Czartoryskich [dalej: Bibl. XX. Cz.], sygn. 1190 I Cim). 
nimowo druk nosi tytuł: Krótkie a prawdziwe opisanie dysputacyjej,

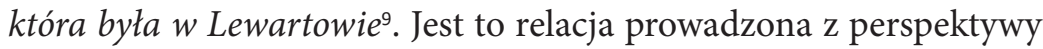
unitariańskiej. Autorem był zapewne jeden z ariańskich dysputantów: Wojciech z Kalisza ${ }^{10}$ lub Jan Niemojewski ${ }^{11}$. W analizach pomijam jawnie stronniczy wierszowany opis tej dysputy: Pogrom lewartowski, pióra najpewniej Adriana Radzymińskiego ${ }^{12}$.

3) Dysputa zorganizowana w Lublinie 22-23 maja 1592 roku była kontynuacją dysputy lewartowskiej. Przedłożone tezy były takie same jak cztery miesiące wcześniej w Lewartowie. Dysputację rzekomo planowano jako trójstronną, jednak ewangelicy twierdzili, że nie zostali o niej uprzedzeni, i nie przysłali dysputatorów. Starli się zatem wyłącznie Adrian Radzymiński SI (proponens) z unitarianinem Piotrem Statoriusem młodszym (opponens). Posiadamy dwie symetryczne relacje: wydaną przez Radzymińskiego, ukrywającego się pod pseudonimem Jan Przylepski, Dysputacyję lubelską ks. Adryjana Radzymińskiego [...] o przedwieczności Bóstwa Pana i Boga naszego Jezusa Chrystusa ${ }^{13}$ oraz Piotra Statoriusa-Stojeńskiego mł., Dysputacyję lubelska Piotra Statoriusa [...] o przedwiecznym Bóstwie Syna Bożego ${ }^{14}$.

9 [Wojciech z Kalisza], Krótkie a prawdziwe opisanie dysputacyjej, która była w Lewartowie anno 1592 d. 13 i 14 stycznia, w której ks. Radziminski theses dat, a Calissius rektor lewartowski $i$ ks. Franciszek minister kurowski i pan Jan Niemojewski opugnowali, Kraków: Sebastian Sternacki, [1592] (Bibl. XX. Cz., sygn. 1932 I Cim).

10 S. Tworek, Dysputa lewartowska..., s. 52.

11 K. Estreicher, Bibliografia polska, t. 23, Kraków 1910, s. 124.

12 Karol Estreicher jako autora Pogromu lewartowskiego wskazuje Marcina Łaszcza. K. Estreicher, Bibliografia polska, t. 21, Kraków 1906, s. 105-106.

13 J. Przylepski [A. Radzymiński], Dysputacyja lubelska ks. Adryjana Radzymińskiego [...] z Statoriuszem ministrem nowokrzczeńskim o przedwieczności Bóstwa Pana i Boga naszego Jezusa Chrystusa dnia 22 i 23 maja roku 1592, Kraków: Jakub Siebeneicher, 1592 (Biblioteka Narodowa [dalej: BN], sygn. SD XVI.Qu.26); https:// polona.pl/item/dispvtacia-lvbelska-X-adryana-radzyminskiego-z-statoryuszem-o,NjgyMzY5NDg/4/\#info:metadata (dostęp: 5.02.2018).

${ }_{14}$ P. Statorius-Stojeński mł., Dysputacyja lubelska Piotra Statoriusa sługi słowa Bożego o przedwiecznym Bóstwie Syna Bożego z ks. Adryjanem Radzimińskim Jezuitą, [Kraków:] Aleksy Rodecki, [1592] (BN, sygn. SD XVI.Qu.6426); https://polona.pl/ 
4) Druga dysputacja śmigielska z 2 lipca 1592 roku. Tym razem oponentem Hieronima Powodowskiego był Krzysztof Ostorode, który w 1592 roku przejął po Krotowicjuszu przewodnictwo w zborze braci polskich w Śmiglu; tematem był dogmat o Trójcy Świętej oraz chrzest małych dzieci. Relacja Krzysztofa Ostorodego nie dochowała się $e^{15}$, posiadamy wyłącznie tekst autora katolickiego, prawdopodobnie samego Powodowskiego, Disputacyja wtóra ks. Hieronima Powodowskiego źsmigielskimi różnobożany ${ }^{16}$.

5) Dysputa nowogrodzka (24-25 stycznia 1594 r.) między Marcinem Śmigleckim SI a Janem Licyniuszem. Dysputę trwającą w pierwszym dniu sześć godzin kontynuowano w dniu następnym. Tezy do dysputy przedkładał Śmiglecki. Dotyczyły po raz kolejny przedwiecznego bóstwa Chrystusa. Istnieje jedna szczegółowa relacja z przebiegu tej dysputy: Opisanie dysputacyjej nowogrodzkiej, która miał ks. Marcin Śmiglecki [...] z Janem Licyniuszem ${ }^{17}$.

6) Dysputacja wileńska (2 czerwca 1599 r.). Katolików reprezentował Marcin Śmiglecki, a ewangelików Daniel Mikołajewski. Tematem był prymat papieża (primatus Petri). W tym przypadku posiadamy dwie relacje autorstwa obu głównych dysputantów: Marcina Śmigleckiego, Dysputacyję wileńska, która miał ks. Marcin Śmiglecki Societatis Iesu z ministrami ewanjelickimi [...] o jednej widomej

item/dyspvtacia-lvbelska-piotra-statorivsa-slugi-slowa-bozego-o-przedwiecznymbostwie-syna,Njc1NzU3OTQ/6/\#info:metadata (dostęp: 5.02.2018).

15 K. Ostorode, Dysputacyja zboru szmigielskiego, która miał Cristoph Osterod sługa słowa Bożego na tamtem miejscu z ks. Hieronimem Powodowskim [...] 1592 dnia 2 lipca o tym, że on jedyny Bóg nie jest trzy persony to jest jako mówią, Ojciec, Syn i Duch Ś<wię>ty, ale tylko sam Ojciec a żaden inny [...], [b.m. i r. w.]. Zob. K. Estreicher, Bibliografia polska, t. 23, s. 495.

16 [H. Powodowski], Dysputacyja wtóra ks. Hieronima Powodowskiego z śmigielskimi różnobożany. O trzech personach w jednymże Bóstwie i o krzczeniu małych dziatek. Odprawowana w Śmiglu 2 dnia lipca roku 1592, Poznań: Barbara Wolrab i dziedzice Jana Wolraba, 1592 (Bibl. XX. Cz., sygn. 1129 I Cim).

${ }_{17}$ [M. Śmiglecki], Opisanie dysputacyjej nowogrodzkiej, która miał ks. Marcin Śmiglecki [...] z Janem Licyniuszem, Wilno: Drukarnia Akademii Societatis Iesu, [po 25.01.1594] (Bibl. XX. Cz., sygn. 952 I Cim). 
głowie Kościoła Bożego ${ }^{18}$ oraz Daniela Mikołajewskiego, Dysputacyje wileńska, która miał ks. Marcin Śmiglecki Soc<ietatis> Jesu z ks. Danielem Mikołajewskim [...] de primatu Petri ${ }^{19}$.

Wspólną cechą wszystkich ośmiu druków jest szczegółowe przedstawienie przebiegu dysputy. Wszystkie - choć pisane z odmiennych perspektyw wyznaniowych - przytaczają naprzemiennie posunięcia obu dysputantów. Celem jest szczegółowe zapoznanie czytelników z przebiegiem dialektycznego procesu obrony i atakowania tez. Wszystkie druki zamieszczają zapewnienia, że czytelnik samodzielnie może wyrobić sobie pogląd odnośnie do wygranej lub przegranej którejś ze stron.

Pomijam wszelkie druki, które powstały w związku z tymi sześcioma dysputami, ale mają inną formę, przykładowo: Hieronima Powodowskiego, Weryfikacyja dysputacyjej wtórej śmigielskiej, o personach nierozdzielnego Bóstwa Trójce Ś <więtej>; Marcina Gerticha, Protestacyja przeciwko niestusznej chlubie tych, co za przyczyna Dysputacyjej ks. Marcina Śmigleckiego [...] przed zwycięstwem tryjumfują (Wilno 1599); Jana Białuskiego, Łupierze martwe skryptu Marcina Gracjana ministra [...] (Wilno 1599); Hieronima Stefanowskiego, Termin na Protestacyja ministra jednego ewenjelickiego [...] (Wilno 1599) czy tegoż Censura dysputacyjej wileńskiej podanej przez Daniela Mikołajewskiego [...] $\left(\right.$ Wilno, 1600 ${ }^{20}$. Nie uwzględniam - tym bardziej - polemicznych replik, które stanowią kontynuację sporu doktrynalnego, będącego tematem publicznej dysputy (np. Marcina

18 [M. Śmiglecki], Dysputacyja wileńska, którą miał ks. Marcin Śmiglecki Societatis Iesu z ministrami ewanjelickimi [...] o jednej widomej głowie Kościoła Bożego, Kraków: Drukarnia Łazarzowa, 1599 (Bibl. XX. Cz., sygn. Cim. 912 II).

19 D. Mikołajewski, Dysputacyja wileńska, która miał ks. Marcin Śmiglecki Soc< ietatis > Jesu z ks. Danielem Mikołajewskim, sługa Słowa Bożego de prymatu Petri, Toruń: Andrzej Koteniusz, 1599 (Biblioteka Jagiellońska, sygn. Cim.Qu.5026).

20 Wykaz - jakkolwiek niepełny - druków związanych z dysputami katolików z innowiercami zamieścił Bronisław Natoński w przypisie 113 (s. 127-128) do swojej książki Humanizm jezuicki i teologia pozytywno-kontrowersyjna... Wykaz obejmuje 32 druki z XVI i XVII wieku. 
Śmigleckiego, O jednej widomej głowie Kościoła Bożego [...] naprzeciw błędom teraźniejszym i skryptom niektórych ministrów ewanjelickich [...], Wilno 1600).

Wszystkie teksty źródłowe pisane były z jakiejś zaangażowanej perspektywy. Sporządzili je albo świadkowie-obserwatorzy, albo sami dysputanci, często ukrywający się pod fikcyjnymi imionami lub publikujący anonimowo. Zatem nawet jeśli teksty szczegółowo przytaczają przebieg dysputy, nie mamy do czynienia z bezstronnym świadectwem (inne pytanie, czy takie bezstronne świadectwo w ogóle byłoby możliwe). Często pojawiają się wartościujące komentarze, oceny, parafrazy czy summa argumentu w miejsce całej wypowiedzi. Równocześnie obserwujemy bogatą gamę retorycznych zabiegów uwiarygodniania własnego przekazu, który ma się jawić jako rzeczowy i nieuprzedzony. W dwóch wypadkach posiadamy obustronne opisy dysput, które można konfrontować.

\section{Pożytki druku}

Mimo dobrze udokumentowanej krytycznej postawy wielu humanistów wobec scholastycznej dysputy ${ }^{21} \mathrm{w}$ okresie renesansu jest ona nadal podstawową, obok lectio, czyli wykładu z komentarzem do tekstu, metodą szkolnego nauczania ${ }^{22}$. Co więcej, wbrew oskarżeniom

21 Zob. R. Guerlac, Introduction, w: J.L. Vives, Against the Pseudodialecticians. A Humanist Attack on Medieval Logic, transl., intr., notes by R. Guerlac, Dodrecht 1979, s. 1-43; N.W. Gilbert, The Early Italian Humanists and Disputation, w: Renaissance Studies in Honor of Hans Baron, ed. by A. Molho, J.A.Tedeschi, DeKalb (Ill.) 1971, s. 203-226; P.O. Kristeller, Medieval Aspects of Reneissance Learning, New York 1992, s. 10. Klasyczną pozycją na temat scholastyczno-humanistycznego sporu pozostaje: E. Rummel, The Humanist-Scholastic Deabate in the Renaissance and Reformation, Cambridge 1995. Olga Weijers podkreśla, że należy odróżnić ataki humanistów skierowane przeciw dialektyce od ich postawy wobec samej dysputy (dobrą dysputę uważali za bardzo przydatną), O. Weijers, Renaissance Disputation, s. 185-189.

22 O. Weijers, Renaissance Disputation, s. 180. 
niektórych humanistów o jałowość czy sztuczność, była ona efektywną metodą, kształcącą krytyczne myślenie. Już u samych początków reformacji z fakultetów teologicznych przenosi się poza krąg społeczności akademickiej (95 tez ogłoszonych przez Lutra w $1517 \mathrm{r}$. było przecież tezami do dysputy). Struktura disputatio ufundowana na rozbieżności stanowisk oraz jej popularność jako metody szkolnej, a co za tym idzie powszechna wśród ludzi wykształconych znajomość jej reguł oraz dialektycznych narzędzi, pozwalały łatwo zaangażować tę formę na użytek wyznaniowych walk w okresie reformacji.

W drugiej połowie XVI wieku reformacja w Polsce wchodzi w okres konfesjonalizacji. Publicznych dysput wyznaniowych między przedstawicielami dwóch lub więcej wyznań jest coraz więcej, czemu niewątpliwie sprzyjała konfederacja warszawska (pax dissidentium), od stycznia 1573 roku gwarantująca szlachcie swobodę religijną. O ile propagandowa siła żywego słowa brała górę nad spisanymi tekstami ${ }^{23}$, o tyle druk stwarzał szanse na bezprecedensowe poszerzenie kręgu odbiorców. Autor Opisania dysputacyjej nowogrodzkiej, najpewniej sam Marcin Śmiglecki, w przedmowie Do Czytelnika pisze, że pragnął płynące z tej dysputy pożytki i pociechy udostępnić wszystkim tym, którzy osobiście nie mogli się jej przysłuchiwać:

Aby jakom ja sam, ze wszystkimi prawowiernymi słuchając, pociechę i pożytek niewymowny z niej odniósł, i ciebie też, któryś tam obecny być nie mógł, czytaniem jej tejże pociechy i pożytku uczesnikiem uczynił²4.

23 Wiesław Stec zwraca uwagę na to, że publiczne dysputy stanowiły swoistą atrakcję, określa je mianem „faktów ludycznych”, W. Stec, Literacki kształt polemik antyjezuickich..., s. 114, 119.

24 [M. Śmiglecki], Opisanie dysputacyjej nowogrodzkiej..., s. [1]. Cytaty podaję $\mathrm{w}$ transkrypcji modernizującej interpunkcję, pisownię wielkich liter (respektując niekiedy autorskie względy uczuciowe i grzecznościowe) oraz w dużej mierze system ortograficzny. Nie zachowuję kreskowania $a$, e. Ó wprowadzam wszędzie tam, gdzie występuje obecnie. Stosuję dzisiejszą pisownię głosek $i, j, y$. Nie respektuję podwojonych spółgłosek. W transkrypcji wyrazów o fleksji zgodnej z regułami pol- 
Drukowana relacja $\mathrm{z}$ dysputy przychodzi ponadto w sukurs zawodnej ludzkiej pamięci. Stanowi trwałe świadectwo ulotnego ze swej natury wydarzenia, jakim było ustne starcie. Hieronim Powodowski, oponent Krzysztofa Ostorodego w dyspucie w Śmiglu z 2 lipca 1592, uzasadniając wydanie drukiem relacji z dysputy, pisze:

[...] iż prze kwapienie i niedostatecznie się o czasie porozumienie, niemało ludzi ślacheckich tej rosprawy omieszkali, którzy jej z dawna pragnęli. A ci, którzy słuchali abo nierychło przybywali, abo nie wszytkiego w pamięci zachować mogli i różnie to sobie potym przypominali ${ }^{25}$.

\section{4. „Prawdy szukając przez dysputacyję”}

W omawianych drukach częstokroć napotykamy przekonanie, dziedziczone niewątpliwie po okresie wcześniejszym, iż dysputa służy ujawnianiu prawdy. Definiowane w ten sposób cele dysputy formułowano zazwyczaj w mowach, które zwyczajowo wygłaszane były przez reprezentantów obu stron bezpośrednio przed samą dysputą. Minister zboru ariańskiego w Śmiglu Jan Krotowski miał powiedzieć, że dysputa służy „ku zbudowaniu słuchaczów, aby zrozumieli, przy kim jest prawda”, i żądał by „,druga strona ku temuż się miała”26. Jedenaście lat później, również w Śmiglu, Krzysztof Lubieniecki, działacz i polemista ariański, w uroczystej przemowie miał wyrażać wdzięczność Hieronimowi Powodowskiemu za przyjazd na dysputę „dla pokazania prawdy zbawiennej. W której acz [chrystyjanie - M.R.K] się dobrze poczuwają, jednak rozmaicie bywają

szczyzny usuwam pozostałości grafii łacińskiej (np. disputatia $\rightarrow$ dysputacyja). Usuwam oznaczenia nosowości wtórnej.

25 [H. Powodowski], Dysputacyja wtóra..., k. A v.

26 S. Szamotulski [H. Powodowski?], Dysputacyja ks. Hieronima Powodowskiego..., k. A 5 v. 
z tąd udawani, ku ohydzeniu ludzkiemu"27. Piotr Statorius młodszy, który jako opponens stawał przeciwko Adrianowi Radzymińskiemu w dyspucie lubelskiej (22 maja 1592 r.), w podobnym duchu przypominał adwersarzowi, iż ,tu nie wygranej jeden nad drugim szukać mamy, ale chwały i prawdy Bożej" ${ }^{28}$. A bezpośrednio przed dysputą, gdy mu przeszkadzano hałasami, skarżył się na katolików:

Gdy ksiądz Radzymiński prefacyją czynił, było wielkie milczenie, a gdy ja mówić chcę kilka słów, tedy rozruch, co jeśli dalej będzie, muszę to rozumieć, że tu $\mathrm{W}<$ asze $>\mathrm{M}<$ iłoście $>$ nie szukacie prawdy, ale ją zatłumić chcecie $^{29}$.

Z kolei Daniel Mikołajewski w przedmowie swojej Dysputacyjej wileńskiej cytuje fragment listu Marcina Śmigleckiego, skierowanego do ówczesnego ciwuna wileńskiego Jana Paca, w którym jezuita miał pisać: „Cóż bowiem nam milszego być może jako ludziom prawdę pokazać, która przez opinie heretyckie zaćmiona, przez dysputacyje porządne objaśniona bywa" ${ }^{30}$. W tym samym druku Mikołajewski cytuje też słowa jednego z moderatorów wileńskiej dysputacji, kanclerza wielkiego litewskiego Lwa Sapiehy, który mówił, że „Pana Boga prosić trzeba o pokazanie prawdy przez ten śrzodek dysputacyjej" 31 .

W tekstach - jakkolwiek rzadziej - zdarzają się niekiedy i sceptyczne uwagi na temat pożytków dysputy. Wspomniany wyżej Daniel Mikołajewski pisze w dedykacji skierowanej do Andrzeja Leszczyńskiego:

[...] trudno nawet o pożytku tej dysputacyjej in tanta sententiarum discrepantia [przy tak wielkiej różnicy zdań - M.R.K.] dywinować, gdyż tamże po dysputacyjej mówiły niektóre osoby, że każdy z swą sentencyją do

27 [H. Powodowski], Dysputacyja wtóra..., k. A v.

28 P. Statorius-Stojeński mł., Dysputacyja lubelska..., s. 12.

29 Ibidem, s. 2.

30 D. Mikołajewski, Dysputacyja wileńska..., k. A $\mathrm{r}$.

31 Ibidem, k. C 3 r. 
domu odjedzie, jedna bowiem rzecz i prawda nie jednako od wszystkich po wszystkie czasy przyjmowana była ${ }^{32}$.

Mikołajewski przytacza też słowa Szymona Teofila Turnowskiego, który doszedłszy do głosu przed dysputacją wileńską, mówił:

[...] namniejśmy o tym nie myślili i nie dlategośmy tu przyjechali, żebyśmy z Ich $\mathrm{M}<\mathrm{o}>$ ściami, którzy są rzymskiego nabożeństwa w szranki wstąpić a dysputować mieli, bo wiemy, że mało budują dysputacyje, przy pospolitym doświadczeniu potwierdzają nam tego i samego Krystusa Pana Wodza a Hetmana naszego rozmowy one a dysputacyje, które miewał z ks<iężą $>$ jerozolimską, z faryzeuszami starozakonnemi, których się oni jednak nie nawrócili, ale go na ostatek ukrzyżowali. Wszakże iż za przyczyną Ich $\mathrm{M}<0>$ ść $\mathrm{P}<$ anów $>$ Patronów $\mathrm{z}$ obu stron daną do tego przyszło, aby się tu dysputowało, a tośmy się na ten plac stawili ${ }^{33}$.

Również Hieronim Powodowski sceptycznie wypowiadał się na temat możliwości przekonania adwersarzy do prawdy za pośrednictwem dysputy. Przekonanie bowiem, zdaniem Powodowskiego, „idzie z samego pociągnienia Boskiego, a potym z woli dobrej, której i sam Bóg gwałtu nie czyni”" ${ }^{34}$. Dysputa co prawda może budować pokornych i pobożnych, jednak zacietrzewieni przeciwnicy nie będą w stanie uznać swojej klęski: „nadęci a uporni (jakimi pospolicie heretyki zwłaszcza tej sekty są) by też nabarziej pokonani, tedy się gorszą a zatwardzają i klęskę swą za tryjumf ogłaszają"35.

Niewątpliwie publiczna dysputa wyznaniowa w XVI stuleciu przestaje być szansą na wspólne badanie poprawnych lub błędnych tez dogmatycznych lub teologicznych, a staje się przede wszystkim elementem działań propagandowych. Celem każdego z dysputantów jest teraz obrona własnego stanowiska. Za wszelką cenę. Prowadzo-

32 Ibidem, k. A v.

33 Ibidem, k. C. ${ }_{3}$ v. $-\mathrm{C}_{4}$ r.

34 [H. Powodowski], Dysputacyja wtóra..., k. A ${ }_{6}$.

${ }_{35}$ Ibidem, k. A 6 r.-v. 
na przez reformatorów walka o polszczyznę, znacznie poszerzającą krąg odbiorców dysputy, jest częścią tego zjawiska.

\section{Metody uwiarygodniania dyskursu}

„Nieradzi ludzie słuchaja autorem de se ipso loquentem”

Drukowane relacje z przebiegu dysput w oczywisty sposób narażone są na manipulację. Autorami tekstów są najczęściej sami dysputanci, którzy z racji uwikłania w spór tracą status bezstronnych. $\mathrm{Na}$ problem nierzetelności opisów wynikający z zaangażowania w sprawę zwracał uwagę autor Cenzury dysputacyjej wileńskiej, skierowanej przeciw rzekomo kłamliwemu opisowi tejże dysputy przez Daniela Mikołajewskiego. Hieronim Stefanowski SI ${ }^{36}$, skrywający się pod pseudonimem Marcin Michajłowicz Żagiel, przeprowadza drobiazgową kontrolę sformułowań użytych przez Mikołajewskiego. Cenzurze podlega między innymi uwaga na karcie tytułowej, głosząca, że dysputacja została „od samego autora cale i szczyrze wydana etc.”. Stefanowski przekonuje, że „nieradzi ludzie słuchają autorem de se ipso loquentem [autora, który o sobie samym mówi M.R.K.]"'37. Pisze też:

Iudicium a prawie goły rozumek jest [...] ab hominum iudicio et consuetudine [z osądu i zwyczaju ludzi - M.R.K.], którzy pospolicie in contentioso litigio [w swarliwym sporze - M.R.K.] zwykli się raczej prawdy pytać u trzeciego. A kiedy autor wynidzie i rzecze, jam autor, ja sam prawdę mówię, tedy go sobie palcem ukazują, a słusznie $[\ldots]^{38}$.

36 Zob. K. Estreicher, Bibliografia polska, wyd. S. Estreicher, t. 29, Kraków 1933, s. 272.

37 M.M. Żagiel [H. Stefanowski], Cenzura dysputacyjej wileńskiej [...] abo obrona słuszna szczyrości i zupełności edycyjej katolickiej wileńskiej [...], Wilno: Drukarnia Akademii Societatis Iesu, 1600, k. B r.

38 Ibidem. 
Opis dysputy, który sporządzony został przez jednego z dysputantów, jawi się jako dalszy ciąg polemiki. A to czyni teksty podejrzanymi i niewiarygodnymi. Walka o uwiarygodnienie własnej relacji jest istotnym elementem przekonywania do własnych racji. Jedną ze strategii było publikowanie anonimowo albo ukrywanie autorstwa pod fikcyjnymi imionami.

\section{„Aby ludzie o tej dysputacyjej prawdziwa a dostateczna sprawę mieli"}

To, co jest wspólne dla wszystkich omawianych relacji (bez względu na doktrynalny rodowód autorów), to deklarowana potrzeba przedstawienia prawdziwej wersji zdarzeń. Jest to swoista causa scribendi. Wszystkich autorów bez wyjątku do sięgnięcia po pióro motywuje konieczność przekazania prawdziwych wiadomości o przebiegu i wyniku dysputy. W przypadku relacji, które na rynku wydawniczym ukazywały się jako drugie, powszechnie wykorzystywano motyw oburzenia na kłamliwą wersję adwersarzy oraz konieczność zdemaskowania rozpowszechnianych fałszy (refutatio). Przyjrzyjmy się przykładowej realizacji tego motywu w Dysputacyjej wileńskiej Daniela Mikołajewskiego, który w dedykacji dla Andrzeja Leszczyńskiego podaje dwie przyczyny upublicznienia swojej wersji zdarzeń:

Pierwsza jest różne udawania a tryjumfy przeciwnej strony, która się chełpiła $\mathrm{z}$ tego, iż panowie jezuitowie górę otrzymali i nas ku zawstydzeniu z niemałym swych zbudowaniem a naszych zgorszeniem, przywiedli. Druga przyczyna jest nieszczyre, niedostateczne [...] wydanie tejże dysputacyjej od samego pewnie ks. Śmigleckiego, tamże w Wilnie wyrobione, której dysputacyjej egzemplarz od $\mathrm{W}<$ aszej $>\mathrm{M}<$ iłości $>$ mego $\mathrm{Mi}<\mathfrak{ł o}>$ ściwego Pana mnie przysłany i do edycyjej prętszej i do rekognicyjej a zniesienia $\mathrm{z}$ autentykiem, który u mnie jest, okazyją mi dał. [...] Jednak aby się tym omylnym powieściam i baśniam jakikolwiek wstręt uczynił i aby ludzie o tej dysputacyjej prawdziwą a dostateczną sprawę mieli, a przeczytawszy i dowody z dowodami zniozszy ex aequitate et veritate [bezstronnie i zgodnie z prawdą - M.R.K.] sądzili, ozwać się muszę i Czytelnikowi o tym, com tam mówił albo nie lepszą niż od strony udano, sprawę dać, a to 
bez wszelakich przydatków, odmian i zamilczywania tego, co na ten czas ks. Śmiglecki replikował i mówił³.

Mikołajewski, pragnąc uwiarygodnić przekaz, wzywa na świadków swych słów wszystkich obecnych podczas dysputy, w tym również zwolenników strony przeciwnej:

W czym się nie tylko na $\mathrm{W}<$ aszej $>\mathrm{M}<$ iłości $>$ mego $\mathrm{M}<$ iło>ściwego Pana świadectwo, ale i na Ich $\mathrm{M}<0>$ ść $\mathrm{P}<$ anów $>$ Moderatorów obojej strony $<$ roz>sądek się daję, nawet i do wszystkich słuchaczów, którzy attenti byli na ten czas apeluję, mając za to, że [...] przyznają mi to, żem ja daleko szczyrzej wydał tę rozmowę niż antagonista mój ${ }^{40}$.

Piotr Statorius podobnie rozpoczyna swoją Dysputacyję lubelską:

Nie miałem tej wolej żadnym sposobem czytelniku łaskawy, abym był co o dysputacyjej abo rozmowie, któram miał z ks. Radzymińskim pisać miał, ale iż panowie jezuitowie przeciwko wszelkiej sprawiedliwości nad nadzieję moję z tej dysputacyjej tryjumfują, w druk podawszy tę naszę rozmowę daleko inaczej niż się toczyła, umyśliłem za pomocą Pańską, ine prace na stronę odłożywszy, wydać to miedzy ludzi, com na ten czas przeciwko ks. Radzymińskiemu dysputował i to, co on mnie zadawał abo odpowiedał, ilem pamiętać mógł mowy mojej i mowy jego, a nad to pamięci swej nie dufając, radziłem się tych, którzy tę dysputacyją byli spisali i tak jako od nich była wypisana, tum ją wyłoży ${ }^{41}$.

W tekstach, które ukazywały się jako pierwsze, autorzy zwykle podkreślali, że nie mieli wcale zamysłu wydawania dysputacji drukiem, ale tak wielu ludzi ich o to prosiło, że w końcu czynią zadość tym prośbom. Brak intencji polemicznej niewątpliwie miał przydawać wiarygodności relacji, ponieważ przechwalanie się własnym triumfem w dyspucie było uznawane za wykroczenie przeciw stosowności i interpretowane jako chełpliwość, „szukanie próżnej

39 D. Mikołajewski, Dysputacyja wileńska..., k. $\mathrm{A}_{2} \mathrm{r}$--v.

40 Ibidem, k. A $\mathrm{v}$.

${ }_{41}$ P. Statorius-Stojeński mł., Dysputacyja lubelska..., k. $\mathrm{A}_{2} \mathrm{r}$. 
chwały". W relacjach, które pojawiały się jako pierwsze, również pisano o trudnych do zdzierżenia, bo zupełnie nieprawdziwych przechwałkach przeciwników.

Aczci wprawdzie z razu nic się o tym nie myśliło, aby była drukiem na świat wyniść miała. Lecz barzo wiele ludzi zacnych prośby usilne, aby jej opisanie mieć mogli (którym żądaniu trudno było inaczej dość uczynić) do tego mię naprzód wzbudziły. Do czego potym przystąpiły niewstydliwe pochwałki adwersarzów, którzy w oczy i na placu nic nie wygrawszy, przedsię miedzy swymi po kąciech sobie obyczajem swoim wygraną przypisująą

Również Hieronim Powodowski, domniemany autor Dysputacyjej śmigielskiej, ukrywający się pod pseudonimem Sebastian Szamotulski, usprawiedliwia wydanie tekstu, powołując się na przechwałki ministrów oraz prośby innych osób:

Tej rozmowej wiele się ludzi zrazu na piśmie mieć domagało, czego im jednak ks. Kanonik pozwolić nie chciał, częścią iż z obu stron ex tempore [natychmiast - M.R.K], bez rozmysłu była uczyniona, a częścią widząc, iż okrom tego swarów o wiarę miedzy ludźmi tak jest wiele, że z nich wybrnąć nie mogą. Teraz wziąwszy pewną sprawę ks. Kanonik, iż Minister udawał jako za zwycięstwo tę to dysputacyją przed starszymi lustratorami swymi i inszymi znacznymi osobami, nie chciał tego spisku w ręku moich dłużej trzymać, aby ludzie obaczyli nie próżną chlubę, ale prawdę, przy kim zostawa ${ }^{43}$.

W relacji z Dysputacyjej śmigielskiej wtórej tenże Hieronim Powodowski wskazuje ponadto na korzyści, płynące z "porządnego" (tj. pewnego, prawdziwego) wydania dysputy, bowiem brak wiarygodnej relacji pogłębia tylko waśnie:

Przyszły do rąk moich terminatury tej rozmowej barzo okęszone, niezgodne i od intencyjej obojej strony czasem barzo dalekie, których iż sobie lu-

42 [M. Śmiglecki], Opisanie dysputacyjej nowogrodzkiej..., s. [1].

43 S. Szamotulski [H. Powodowski?], Dysputacyja ks. Hieronima Powodowskiego..., k. A r. $\mathrm{r}$-v. 
dzie podawali, lepiej było i tym ludziom i samym stronam, jakim pewnym wydaniem dogodzić niż roztyrków w tym przyczyniać ${ }^{44}$.

\section{W zgodzie z autentykiem}

Inną strategią uwiarygodnienia przekazu, często współistniejącą z deklaracjami głoszenia prawdy, jest zapewnianie czytelnika, że relacja oparta została na rzetelnym źródle, czyli autentyku, inaczej terminaturze. Były to protokoły spisywane w trakcie dysputy przez moderatorów powoływanych przez każdą ze stron. Autentykami określano również notatki sporządzane na bieżąco podczas dysputy przez samych dysputantów. Marcin Śmiglecki wiarygodność swojego przekazu buduje na podstawie zgodności z takimi właśnie autentykami:

Dowody, które Ministrowie przywodzili, i odpowiedzi na nie ks. Śmigleckiego masz tu Czytelniku, z kilku dostatecznych autentyków na ten czas spisanych, pilnie zebrane i do czytania wszytkim wobec podane, abyś obaczył, jako żadne dowody przeciw prawdzie katolickiej nie służą i służyć nie mogą, która już to półtora tysiąca lat mocnie trwa i trwać będzie do końca świata. Bo sie iścić musi, co Pan obiecał. Bramy piekielne nie przemogą jej ${ }^{45}$.

W Zamknieniu swojej Dysputacyjej wileńskiej Śmiglecki zachęca czytelnika do samodzielnej weryfikacji przekazu. Informuje, że dwa autentyki są dla chętnych dostępne w wileńskim kolegium: „Jeślibyś to pisanie $\mathrm{z}$ autentykiem znieść chciał, możesz zawżdy dosiąc dwóch autentyków, które na to są w Collegium w Wilnie"46. Praktyka zapoznawania się z pisemnymi dokumentami, poświadczającymi prze-

44 [H. Powodowski], Dysputacyja wtóra..., k. A 2 .

45 [M. Śmiglecki], Dysputacyja wileńska..., k. A ${ }_{3}$.

46 Ibidem, k. E $\mathrm{v}$. 
bieg dysputy, przywodzi na myśl scholastyczną tradycję dostarczania przez mistrza determinatio ${ }^{47}$.

Przykład Śmigleckiego jest jedynym tak precyzyjnym odesłaniem do autentyków. W rzeczywistości wejście w posiadanie protokołów było kłopotliwe, a niekiedy zapewne zupełnie niemożliwe. W drukach spotykamy wzmianki o tym, że sami dysputatorzy miewali problemy z pozyskaniem owych autentyków.

Hieronim Powodowski wspominał kłopoty z dostępem do terminatur:

Mając tedy tak ważne i insze, które opuszczam, przyczyny wydać postępek tej rozmowej, a nie mogąc terminatur dostatecznych dostać, szukałem tego u tych tam samych zborowników przez ks. Plebana tamże Śmigielskiego, aby mi byli posłali obrony swe, którekolwiek jedno przeciw moim przywodzili, gdyż pamięć moja konceptami swymi zabawiona, wszytkiego zachować nie mogła. Ale gdy się z tego wymówili, a ja dłużej czekaciem nie mógł, mając przed sobą drogę w sprawach $\mathrm{R}<$ zeczypospolitej> ludziom nie tajną, tedy tę rozprawę wydawam i spisuję jako nalepiej i z pamięci własnej i z terminatur, którychem po kęsu dostawa $1^{48}$.

Wydaje się jednak, że już sama możliwość weryfikacji relacji z protokołem - wyrażana jako zachęta: „Sprawdź mnie, jeśli chcesz" - miała dużą siłę psychologiczną i funkcjonowała na zasadzie argumentu entymematycznego: „Nie boję się weryfikacji, bo mówię prawdę". Autentyk miał niewątpliwie status rzetelnego, niezmanipulowanego zapisu. Wobec okazjonalności i ulotności samego zdarzenia, jakim była dysputa, oraz wobec zawodności ludzkiej pamięci terminatury stawały się gwarantem prawdziwości przekazu. Daniel Mikołajewski choć twierdził, że wcale nie miał zamysłu wydawać swojej relacji drukiem, to jednak zapewniał czytelników, że gdy tylko po zakończonej dyspucie wileńskiej przybył do domu, zaraz wszystko $\mathrm{z}$ autentyku przepisał ${ }^{49}$.

47 Zob. przypis 5.

48 [H. Powodowski], Dysputacyja wtóra..., k. A $\mathrm{A}_{2} \mathrm{v} . \mathrm{A}_{3} \mathrm{r}$.

49 [D. Mikołajewski], Dysputacyja wileńska..., k. $\mathrm{A}_{2} \mathrm{r}$. 
Autor Opisania dysputacyjej nowogrodzkiej, najpewniej Marcin Śmiglecki, deklaruje, że mu do „wiernego, szczyrego, a niemal do słowa dostatecznego" opisania dysputy nowogrodzkiej pomogło zweryfikowanie własnej wersji z wersją adwersarzy. Taka procedura miała przeciwdziałać późniejszym oskarżeniom oponentów, że relacja jest zafałszowana:

Starał się bowiem sam ks. Śmiglecki pilnie o to, żeby opisanie tej dysputacyjej i wierne, i ważne było. Aby mu słusznie żaden dać w czym przygany albo wiary ująć nie mógł. Dlaczego zaraz po dysputacyjej upomniał się, aby wedle kondycyj obu stron spisanie zniesione było, co adwersarze jako ochotnie obiecali, tak i ochotnie nie spełnili. Potym zasię Lycyniusza samego, acz z trudnością, aby swój skrypt z naszym pospołu czytał, przywiedziono. $\mathrm{Na}$ co z przodku ociągając się odpowiedział, że pry żadnego statecznego i dostatecznego skryptu nie mamy, a każdy który pisał, swoje z sobą pisania wzięli. Wszakże potym pokazał i użyczył, co sam dla siebie z pamięci był napisał. W który skrypt wejrzawszy, acz barzo z strony naszej niedostateczny (bo czym mu nabarziej dogrzewano, to ledwie dotknąwszy przeminoł, a drugich rzeczy nie wspominał) z niego dostatecznie się wyjęło, co by rzeczy jego pomocne być mogło, aby nie miał w czym się na nas uskarżać ${ }^{50}$.

"Jako i sam z tej dysputacyjej obaczyć snadnie będziesz mógł"

Kolejną dostrzegalną strategią, wpisującą się w poczet zabiegów tworzenia iluzji obiektywności i prawdziwości relacji, jest deklarowanie wiary w zdolność czytelnika do samodzielnego ocenienia, po czyjej stronie jest prawda. „Przyczyna tedy była z niemałej części wydania tej dysputacyjej ta, aby każdy miłośnik prawdy onej szukając, z czytania jej dojść mógł"

Podobne zapewnienia możemy znaleźć zarówno w katolickiej, jak i nowowierczej relacji z dysputacji lubelskiej. Adrian Radzymiński pisze:

50 [M. Śmiglecki], Opisanie dysputacyjej nowogrodzkiej..., s. [2-3].

51 [M. Śmiglecki], Dysputacyja wileńska..., k. A r. $\mathrm{r}$-v. 
Toczyła się ta dysputacyja w kole zacnych i senatorskich i rycerskich ludzi [...] tak katolików, jako i ewangelików, którzy wszyscy, że przegraną nowokrzczeńcy mieli, jaśnie zeznawali, jako i sam z tej dysputacyjej obaczyć snadnie będziesz mógł ${ }^{52}$.

\section{Piotr Statorius:}

Naprzód cię tedy proszę, ktokolwiek jesteś, abyś praeiudicatam opinionem [osąd pełen uprzedzeń - M.R.K.] na stronę odłożywszy pilnie uważał, jako moje zadawania, tak ks. Radzimińskiego odpowiedzi, abo moje odpowiedzi a jego zadawania. Gdzie snadnie obaczyć będziesz mógł, iż się przy żadnej odpowiedzi swej ostać nie mógł, ale co raz inszą rzecz wnosił nową, aby tylko ludziom rozsądek zaćmił i aby się nie zdał, że nie mógł odpowiedaćs3.

Czytelnikowi narzucana jest w ten sposób rola arbitra. Staje się on sprzymierzeńcem autora, $\mathrm{z}$ którym ma zbieżne cele: jednemu chodzi o głoszenie prawdy, drugiemu o jej poznanie. Wszyscy autorzy co rusz deklarują wiarę w kompetencje czytelnika, równocześnie nieustannie nim sterując - podpowiadają sygnały zwycięstwa i przegranej w dyspucie. Najdalej w edukowaniu czytelnika, na czym polegają symptomy przegranej adwersarzy, posuwa się Marcin Śmiglecki. W Opisaniu dysputacyjej nowogrodzkiej zamieszcza szczegółowy opis dwóch podstępnych „sztuk a omylnych forteli”, którymi kacerze prostego słuchacza mamią:

Naprzód ta ich sztuka jest naprzedniejsza: nigdy na argument directe nie odpowiedzieć, ale dawszy mu pokój, długim mówienim i pisma przywodzenim co inszego pokazować, o czym sporu ani wzmianki nie masz w położonym argumencie. Jako kiedy mu pokażesz pismo, które jaśnie Chrystusowi Bóstwo przypisuje. Cóż on na to? Nie może to być. Jeden jest Bóg. Chrystus jest człowiek. Widzisz, jako nie do rzeczy mówi. Bo kto kiedy z naszych twierdził to, aby Bóg jeden nie był albo Chrystus nie był człowiekiem $^{54}$.

52 J. Przylepski [A. Radzymiński], Dysputacyja lubelska..., k. A v.

53 P. Statorius-Stojeński mł., Dysputacyja lubelska..., k. A r.

54 [M. Śmiglecki], Opisanie dysputacyjej nowogrodzkiej..., s. [3]. 
Druga sztuka niepośledniejsza. Kiedy im jasne pismo pokażesz, na które odpowiedzieć nie mogą, to skoczą do drugiego pisma, w których się takie słowa najdują, gdzie iż o czym inszym one słowa są rzeczone, inaczej się też rozumieć muszą. A u nich wszystko musi się jednako rozumieć. Jako na przykład, kilka razy pismo zowie człowieka omnis creatura [całe stworzenie - M.R.K.], skąd oni, żeby Chrystusowi z Pawłem nie przyznali stworzenia wszechrzeczy, tak miejsce Pawła św. primogenitus omnis creaturae, quoniam in ipso condita sunt universa [Pierworodny wobec każdego stworzenia, bo w Nim zostało wszystko stworzone ${ }^{55}$ ] o człowieku wykładają, przez wszystko stworzenie ludzie rozumiejąc, na przeciw jasnemu pismu, które zaraz przydaje et in coelis et in terra, visibilia et invisibilia [i to, co w niebiosach, i to, co na ziemi, byty widzialne i niewidzialne ${ }^{56}$. A to jest u nich pismo przez pismo wykładaćs ${ }^{57}$.

W późniejszej Dysputacyjej wileńskiej Marcin Śmiglecki wymienia najistotniejsze sygnały braku silnych argumentów w dyspucie: „niepostępowanie dalej”, „powtarzanie ciągle tego samego”, odbieganie od rzeczy - „udawanie się do innych racji”, „cofanie się do wcześniejszego argumentu":

Bo musi tu prawdę rzec: co jest w tych argumentach, skądby sie znaczyło, że Jezuitowie przegrali, Ministrowie wygrali? [...] Jesli ten wygrywa, któremu broń z rąk wybiwszy, postawią go na placu goło, wygrał tak Pan Mikołajewski. Bo ledwie z argumentem na plac wyjechał, za pierwszą odpowiedzią albo nie postępował dalej, nie raz jednoż a jedno powtarzając, albo gdzie indzie skoczył, argumentu i odpowiedzi odbieżawszy. Doznasz tego Czytelniku gdzie sie każdemu z osobna argumentowi przypatrzysz. Ten, który odpowieda w dysputacyjej, na ten czas wygrywa, kiedy odpowiedzią swoją tak zwątli moc argumentu adwersarza, iż prowadzić go da-

55 Cytat łaciński pochodzi z Listu św. Pawła do Kolosan (Kol 1, 15). Dalej podaję tylko sigla, wszystkie przekłady z Pisma Świętego przytaczam za: Pismo Święte Starego i Nowego Testamentu w przekładzie z języków oryginalnych, oprac. zespół biblistów polskich z inicjatywy benedyktynów tynieckich, red. A. Jankowski et al., tłum. W. Borowski et al., wyd. 5, Poznań 2003.

${ }_{56} \mathrm{Kol} 1,16$.

${ }_{57}$ [M. Śmiglecki], Opisanie dysputacyjej nowogrodzkiej..., s. [4-5]. 
lej i popierać nie może. Któryż argument Minister przywiódł, iżby nie był pierwszą dystynkcyją zwątlony ${ }^{58}$

I dalej pyta ironicznie: „Nuż i to jes $<\mathrm{t}>$ li znak zwycięstwa, rzecz pozwoloną znowu rewokować i nazad wracać, co Ministrowi nieraz się trafiło, a Jezuita żadnej sie odpowiedzi nie zawstydził ani sie nazad cofnął" "59.

Niekiedy uciekano się do podawania innych jeszcze symptomów czy „dowodów” przegranej oponentów. Adrian Radzymiński pisał, że adwersarze „nazajutrz po dysputacyjej rozproszyli się jako po przegranej"60. Natomiast Śmiglecki dodatkowo przekonuje czytelnika, że sam Bóg wskazał, po czyjej stronie jest racja i kogo należy uznać za zwycięzcę dysputy w Wilnie:

Lecz si testimonium hominum accipimus, testimonium Dei maius est [Jeśli przyjmujemy świadectwo ludzi - to świadectwo Boże więcej znaczy ${ }^{61}$, pokazał Pan Bóg znacznym i nagłym przypadkiem, czyja prawda. Jeden bowiem z tych tryjumfantów dobrze znajomy, który tu był niedawno od dworu przyjechał, gdy u znacznej osoby urzędnika Jego Król<ewskiej> $\mathrm{M}<$ ości $>$ upornie przed drugimi twierdził, iż swoi wygrali a drudzy wiary mu nie dodawając spór z nim wiedli, zaklął sie aby jutrznie nie doczekał, jeśli jest inaczej, przydawszy niektóre bluźnierstwa przeciwko Mszej $\hat{S}<$ więtej>, Sakramentowi i $\mathrm{P}<$ annie $>$ Maryjej, ustawać nagle począł, i nie tylko jutra (żal się Boże, bo mi był i wielom drugim znajomy), ale wieczora nie doczekał. Tak podczas Pan Bóg złe zaklinanie zrazu nie borgując, płaci. Ale już wolę Czytelniku, że sam z czytania wygraną uznasz, byś jedno odłożywszy na stronę afekty i praeiudicatam opinionem [sąd pełen uprzedzeń - M.R.K.], czytał. Ja com tu przytoczył, zabiegając nazbyt bezpiecznym rozsądkom i kalumniom, przytoczyciem musiał ${ }^{62}$.

Na takie „dowody” Śmigleckiego oburza się Marcin G. Gertich:

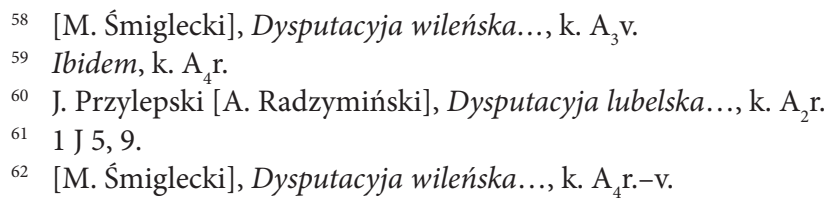


Tego jeszcze dotknąć muszę. Wzmiankę czynią w prefacyjej skryptu swego, kogoś, co według ich powieści, w drodze nagle umrzeć miał, ewangelikom to przyznawszy, że wygrali i zakląwszy się, jeśliby inaczej było. Ale czemu wżdy tej osoby nie mianowali. Wiemy my też, kto z naszych pod ten czas chory $z$ Wilna wyjechał i w drodze umarł, ale żeby za taką przyczyną, jaką oni kładą, nie wiem, czym tego dowiedą, ponieważ ci którzy przy śmierci jego byli, choć różnego od nas nabożeństwa, jednak inaksze o tym świadectwo dają. Aleć $\mathrm{i}$ to nie nowina tym, którym prawdy nie stawa, cudami nadrabiać ${ }^{63}$.

Drukowane relacje polskich dysput wyznaniowych są niewątpliwie cennym, acz wciąż wymagającym szczegółowych badań źródłem do poznania staropolskiej kultury dialektycznej oraz form prowadzenia polemiki doktrynalnej w okresie reformacji. Teksty te poświadczają powszechną wśród ludzi wykształconych znajomość formalnych reguł szkolnej disputatio oraz dążenie - zwłaszcza członków nowych wspólnot chrześcijańskich - do adaptowania tych reguł do religijnych dysput prowadzonych po polsku. Druki relacjonujące takie dysputy poświadczają odziedziczone po średniowieczu przekonania na temat możliwości poznania prawdy za pośrednictwem disputatio oraz wyrażaną explicite wiarę w możliwości czytelników do samodzielnej oceny poprawności formułowanych argumentów i kontrargumentów, a w konsekwencji zrozumienia, po czyjej stronie jest racja. Równocześnie zabiegi dyskursywne służące sterowaniu lekturą czytelniczą (deklaracje etycznego przymusu ujawniania prawdy, zapewnienia o wzorowaniu własnej relacji na autentykach, zatajanie prawdziwego autorstwa tekstu) bezlitośnie podważają zarówno obiektywność tych przekazów, jak i tezę o samowystarczalności dialektyki jako narzędzia ujawniania prawdziwości czy fałszywości teologicznych uzasadnień.

${ }_{63}$ M.G. Gertich, Protestacyja przeciwko niestusznej chlubie tych, co za przyczyna Dysputacyji ks. Marcina Śmigleckiego [...] przed zwycięstwem tryjumfuja, Wilno [b.dr.], 1599, k. A r. 


\section{Bibliografia}

\section{Źródła}

Gertich M.G., Protestacyja przeciwko niestusznej chlubie tych, co za przyczyna Dysputacyji ks. Marcina Śmigleckiego [...] przed zwycięstwem tryjumfują, Wilno [b.dr.] 1599.

Mikołajewski D., Dysputacyja wileńska, którą miał ks. Marcin Śmiglecki Soc<ietatis> Jesu $z$ ks. Danielem Mikołajewskim, sługa Słowa Bożego de prymatu Petri, Toruń: Andrzej Koteniusz, 1599 (Biblioteka Jagiellońska, sygn. Cim.Qu.5026).

Pismo Święte Starego i Nowego Testamentu w przekładzie z języków oryginalnych, oprac. zespół biblistów polskich z inicjatywy benedyktynów tynieckich, red. A. Jankowski et al., tłum. W. Borowski et al., wyd. 5, Poznań 2003.

[Powodowski H.], Dysputacyja wtóra Księdza Hieronima Powodowskiego z śmigielskimi różnobożany. O trzech personach w jednymże Bóstwie i o krzczeniu malych dziatek. Odprawowana w Śmiglu 2 dnia lipca roku 1592, Poznań: Barbara Wolrab i dziedzice Jana Wolraba, 1592 (Biblioteka Książąt Czartoryskich, sygn. 1129 I Cim).

Przylepski J. [Radzymiński A.], Dysputacyja lubelska ks. Adryjana Radzymińskiego [...] z Statoriuszem ministrem nowokrzczeńskim o przedwieczności Bóstwa Pana i Boga naszego Jezusa Chrystusa dnia 22 i 23 maja roku 1592, Kraków: Jakub Siebeneicher, 1592 (Biblioteka Narodowa, sygn. SD XVI.Qu.26); https://polona.pl/item/dispvtacia-lvbelska-X-adryana-radzyminskiego-Z-statoryuszem-o,NjgyMzY5NDg/4/\#info:metadata (dostęp: 5.02.2018).

Statorius-Stojeński mł. P., Dysputacyja lubelska Piotra Statoriusa sługi słowa Bożego o przedwiecznym Bóstwie Syna Bożego z ks. Adryjanem Radzimińskim Jezuita, [Kraków]: Aleksy Rodecki, [1592] (Biblioteka Narodowa, sygn. SD XVI.Qu.6426); https://polona.pl/item/dyspvtacia-lvbelska-piotra-statorivsa-slugi-slowa-bozego-o-przedwiecznym-bostwie-syna,Njc1NzU3OTQ/6/\#info:metadata (dostęp: 5.02. 2018).

Szamotulski S. [Powodowski H.?], Dysputacyja ks. Hieronima Powodowskiego z ministrem zboru nowoariańskiego śmigielskiego Janem Krotowicjuszem, o niektórych artykułach przedwiecznego Bóstwa Syna Bożego i Trójce Przenaświętszej, tamże w zborze śmigielskim odprawowana [...] dnia 27 grudnia w roku 1581, [Poznań: Jan Wolrab, 1581] (Biblioteka Książąt Czartoryskich, sygn. 1190 I Cim).

[Śmiglecki M.], Dysputacyja wileńska, którą miał ks. Marcin Śmiglecki Societatis Iesu $z$ ministrami ewanjelickimi $[. .$.$] o jednej widomej głowie Kościoła Bożego, Kra-$ ków: Drukarnia Łazarzowa, 1599 (Biblioteka Książąt Czartoryskich, sygn. Cim. 912 II). 
[Śmiglecki M.], Opisanie dysputacyjej nowogrodzkiej, którą miał ks. Marcin Śmiglecki [...] z Janem Licyniuszem, Wilno: Drukarnia Akademii Societatis Iesu, [po 25.01.1594] (Biblioteka Książąt Czartoryskich, sygn. 952 I Cim).

[Wojciech z Kalisza], Krótkie a prawdziwe opisanie dysputacyjej, która była w Lewartowie anno 1592 d. 13 i 14 stycznia, w której ks. Radzimiński theses dał, a Calissius rektor lewartowski $i$ ks. Franciszek minister kurowski i pan Jan Niemojewski opugnowali, Kraków: Sebastian Sternacki, [1592] (Biblioteka Książąt Czartoryskich, sygn. 1932 I Cim).

Żagiel M.M. [Stefanowski H.], Cenzura dysputacyjej wileńskiej [...] abo obrona słuszna szczyrości i zupetności edycjej katolickiej wileńskiej [...], Wilno: Drukarnia Akademii Societatis Iesu, 1600.

\section{Opracowania}

Angelelli I., The Techniques of Disputation in the History of Logic, „Journal of Philosophy" 67 (1970), s. 800-815.

Chang K., From Oral Disputation to Written Text. The Transformation of the Disputation in Early Modern Europe, „History of Universities” 19 (2004), no. 2, s. $129-187$.

Drzymała K., Ks. Marcin Śmiglecki T.J., Kraków 1981.

Dysputacje arian polskich, wydał i wstępem poprzedził S. Kot, „Reformacja w Polsce" 7 (1935), s. 341-370.

Estreicher K., Bibliografia polska, t. 21, Kraków 1906.

Estreicher K., Bibliografia polska, t. 23, Kraków 1910.

Estreicher K., Bibliografia polska, wyd. S. Estreicher, t. 29, Kraków 1933.

Felipe D.L., The Post-Medieval ars disputandi, Austin 1991.

Fife R.H., The Revolt of Martin Luther, New York-London 1957.

Gilbert N.W., The Early Italian Humanists and Disputation, w: Renaissance Studies in Honor of Hans Baron, ed. by A. Molho, J.A. Tedeschi, DeKalb (Ill.) 1971, s. 203-226.

Gomolec L., Dzieje miasta Śmigla, Poznań 1960.

Gondek P., Dysputa scholastyczna jako przykład sporu naukowego, „Forum Artis Rhetoricae" 3 (2014), s. 7-22.

Guerlac R., Introduction, w: J.L. Vives, Against the Pseudodialecticians. A Humanist Attack on Medieval Logic, transl., intr., notes by R. Guerlac, Dodrecht 1979, s. $1-43$.

Hendrix S.H., Martin Luther. Visionary Reformer, New Haven 2015.

Kamieniecki J., Zasady prowadzenia dyskursu religijnego zawarte $w$ staropolskich tekstach polemicznych, w: Wyraz i zdanie w językach słowiańskich. Opis, konfrontacja, przekład. 7, red. M. Sarnowski, W. Wysoczański, Wrocław 2009, s. 93-100.

Kot S., Dysputacyj braci polskich katalog z rękopisu Andrzeja Lubienieckiego młodszego, „Reformacja w Polsce” 9-10 (1939), s. 456-464.

Kristeller P.O., Medieval Aspects of Reneissance Learning, New York 1992. 
Natoński B., Humanizm jezuicki i teologia pozytywno-kontrowersyjna od XVI do XVIII wieku. Nauczanie i piśmiennictwo, Kraków 2003 (pierwsze wyd. w: Dzieje teologii katolickiej w Polsce, t. 2: Od odrodzenia do oświecenia, cz. 1: Teologia humanistyczna, red. M. Rechowicz, Lublin 1975).

Paintner U., Aus der Universität auf den Markt. Die disputatio als formprägende Gattung Konfessioneller Polemik im 16. Jahrhundert am Beispiel antijesuitischer Publizistik, w: Disputatio 1200-1800. Form, Funktion und Wirkung eines Leitmediums Universitarer Wissenskultur, hrsg. von M. Gindhart, U. Kundert, BerlinNew York 2010, s. 129-154.

Rodda J., Public Religious Disputation in England, 1558-1626, Farnham 2014.

Rummel E., The Humanist-Scholastic Deabate in the Renaissance and Reformation, Cambridge 1995.

Ryszka-Kurczab M., Kilka uwag o Dysputacyjej Księdza Hieronima Powodowskiego $z$ ministrem zboru nowoariańskiego śmigielskiego Janem Krotowicjusem z 1581 roku, w: Rzeczy minionych pamięć. Studia dedykowane Profesorowi Tadeuszowi Ulewiczowi w 90. rocznicę urodzin, red. A. Borowski, J. Niedźwiedź, Kraków 2007, s. 449-462.

Stec W., Literacki kształt polemik antyjezuickich z lat 1578-1625, Białystok 1988.

Tazbir J., Polemika Jakuba Niemojewskiego z jezuitami poznańskimi, w: Munera Poznaniensia. Ksiega pamiatkowa Uniwersytetu im. Adama Mickiewicza w Poznaniu dla uczczenia 600-lecia założenia Uniwersytetu Jagiellońskiego, red. G. Labuda, Poznań 1965, s. 236-260.

Tazbir J., Rola żywego stowa w polskiej propagandzie wyznaniowej, „Kwartalnik Historyczny" 87 (1980), nr 2, s. 291-309.

Tworek S., Dysputa lewartowska w 1592 roku, „Rocznik Lubelski” 3 (1960), s. 51-62.

Weijers O., The Development of Disputation Between the Middle Ages and Renaissance, w: Continuities and Disruptions Between the Middle Ages and the Renaissance. Proceedings of the Colloquium Held at the Warburg Institute, 15-16 June 2007, Jointly Organised by the Warburg Institute and the Gabinete de Filosofia Medieval, ed. by C. Burnett, J. Meirinhos, J. Hamesse, Louvain-la-Neuve 2008, s. $139-150$.

Weijers O., Disputation in the Medieval Universities. General Analysis, w: eadem, In Search of the Truth. A History of Disputation Techniques from Antiquity to Early Modern Times, Turnhout 2013, s. 119-147.

Weijers O., Renaissance Disputation, w: eadem, In Search of the Truth. A History of Disputation Techniques from Antiquity to Early Modern Times, Turnhout 2013, s. 177-207. 